\title{
Expressing, Communicating, Sharing and Representing Grief and Sorrow with Organised Sound (Musings in Eight Short Segments)
}

\author{
Marcello Sorce Keller
}

\section{Section I. Marcus Cato and Me}

In Ancient Rome Marcus Cato (234-149 BC), commonly surnamed the Censor, or the Wise, would often speak up in the Senate and, whatever the topic under discussion, he would unfailingly start with words such as 'the City of Carthage must be destroyed' ('Carthago delenda est'). He was obsessed with the idea that Carthage, the great power competing with Rome for dominance in the Mediterranean, should be annihilated. At some point, the Phoenician city was indeed destroyed by the Romans.

It is impossible for me to feel strongly about power struggles that took place in antiquity, but I carry an obsession myself, somewhat like Marcus Cato did, and I know what it feels like having one; however, the one I have is, luckily, harmless. Whatever musical topic is put on the table, I cannot help taking it as an opportunity to observe and check whether it offers any good reasons to review, refine or possibly correct our general idea of what 'music' is. That is probably because, already at the beginning of my professional life, I had to completely revise my own concept of music. ${ }^{1}$ There was a lot of revising to do because my early training took place at the Milan conservatory, the atmosphere of which could not have been more exclusively rooted in the Western tradition, to the exclusion of all others. ${ }^{2}$ Moreover, in Milan I was indoctrinated to believe in that cluster of Romantic leftovers that still lingers in most conservatories: 'great art is immortal', 'its import is intrinsic to the work itself', 'produced by a genius', 'result of a single creative mind', and so on; they are all residual

\footnotetext{
1 My latest revisitation and revision of the concept are expressed in a recent article: Sorce Keller, Marcello 2010, 'Was ist Musik? Einige Gründe dafür, warum wir die 〈Musik〉 nicht mehr als 〈Musik〉 bezeichnen sollten', Schweizer Jahrbuch für Musikwissenschaft, vol. 30, pp. 11-26 [later appeared as 'Che cosa è la musica e perché, forse, non dovremmo più chiamarla "musica"', Musica/Realtà, vol. 1, pp. 33-56].

2 Puccini, Mascagni, Ponchielli, Berio, Muti, Pollini — only to mention a few-all studied there and make up the pantheon students are supposed to venerate; never mind if they are never told about Charlie Parker, Miles Davis, A. L. Webber, the Trimurti of Indian classical music (Syama Sastri, Tyagaraja, Muttuswamy Dikshitar) or the more recent Ravi Shankar, or the contemporary Bollywood wizard composer A. R. Rahman.
} 
Romantic attitudes that later, during my doctoral training in sociology and ethnomusicology, I completely rejected. Now I am constantly on guard, ready for clues that may lead me to change my mind once again on concepts and ideas we may uncritically take for granted. ${ }^{3}$ After all, our understanding of reality is at best incomplete and, therefore, always provisional.

The subject of 'laments' - chosen for the ICTM Colloquium that was held at The Australian National University in Canberra in 2011, for which this article was prepared-immediately appeared to me as a wonderful opportunity to cultivate my 'obsession', and venture a few considerations that go a bit beyond the subject itself.

\section{Section II. Laments and their Archaic Features}

The experience of sorrow is certainly universal. Forms of behaviour meant to express, communicate and share loss and bereavement - with or through organised sound - exist across most cultures, just like other practices where organised sound relates to the life cycle: lullabies, nursery rhymes, love songs, marriage songs, carols, and so on. Early twentieth-century German ethnologists of the Kulturkreislehre School believed forms of sonic behaviour expressing grief and sorrow, along with yodel, healing songs and cattle calls, represent an archaic surviving layer of European (and possibly universal) folklore. ${ }^{4}$ Kulturkreis theories - never adopted in France, Britain and North Americaare today abandoned, given the more culture-specific and historically shorterrange interests of work done today. ${ }^{5}$ And yet no-one has proved the Kulturkreis approach to be wrong so far. Indeed, laments, yodel, healing songs and cattle calls frequently exhibit a characteristic 'tumbling strain profile' (a gradually

3 There is no shortage of opportunities to do so, as in the course of time new areas of intellectual endeavour emerge - for instance, 'zoomusicology' and 'ecomusicology' — which antagonise and challenge my accepted views on organised sound. Sorce Keller, Marcello 2012, 'Zoomusicology and ethnomusicology: a marriage to celebrate in Heaven', Yearbook for Traditional Music, vol. 43; Sorce Keller, Marcello 2012, 'The windmills of my mind. Musings about Haydn, Kant, sonic ecology, and hygiene', in Gisa Jähnichen (ed.), Music in and as Environment, Department of Human Ecology of Universiti Putra Malaysia, Kuala Lumpur.

4 Schneider, Albrecht 1976, Musikwissenschaft und Kulturkreislehre: zur Methodik und Geschichte der vergleichenden Musikwissenschaft, Verlag für systhematische Musikwissenschaft, Bonn; Schneider, Albrecht 1987, 'Stil, Schicht, Stratigraphie und Geschichte der Volksmusik. Zur historischen Erforschung oral tradierter Musik', Studia Musicologica, vol. 20, pp. 339-59. Fritz Graebner formulated the theory of cultural strata and cycles - named in German Kulturkreislehre - and organically developed it in Methode der Ethnologie (1911, Winters Universitätsbuchhandlung, Heidelberg). His central idea was that the distribution of culture traits indicates not only former cultural contacts (monogenesis), but also strata of cultural history.

5 Cultural relativism, as formulated by the school of Boas, Mead, Benedict and Bateson, assumed cultures to be intrinsic and almost impossible to compare. Their attitude was very influential in triggering the transition from 'comparative musicology' to 'ethnomusicology' and, indeed, ethnomusicology moved away from comparative studies and emphasised acquisition of in-depth knowledge in circumscribed contexts. As ethnomusicology gained ground in Europe, the German Kulturkreislehere, oriented as it was towards worldscale comparisons, went out of fashion. 
descending melodic contour and a 'decrescendo', as the singer runs out of breath) that Curt Sachs, Marius Schneider and Walter Wiora-all of them influenced by the Kulturkreis approach-described as an archaic feature. ${ }^{6}$ Laments, yodel, healing songs and cattle calls are also usually - at least in the Mediterranean area - made up of few tones (less than five), and their frequent non-strophic character also seems to point to their antiquity. Whether we look at them from a diffusionist (that is, monogenetic) or, on the contrary, a polygenetic outlook, it does not ultimately make any substantial difference, as both would lead us to believe that such widespread cultural traits go back to a past, prior to recorded history. ${ }^{7}$

\section{Section III. Laments, Oral and Written}

Not only do laments - that is, sound-complemented performances in honour of the dead, conveying grief and sorrow- exist in most cultures but, intriguingly, they also often take diverse forms in different layers of the same culture. ${ }^{8}$ In the West, they are widely present in the oral environment, but its literate tradition as well has cultivated all along forms and genres meant for mourning. In Classical Greece a poetic form (which of course, like all ancient Greek poetry, also entailed organised sound), the Epikedeion, was nothing but a funeral lament and a eulogy for the departed; and the Seikilos Epitaph of 200 BC, the oldest surviving example of a completely notated composition from anywhere in the world, is nothing different. ${ }^{9}$

6 Sachs, Curt 1962, The Wellsprings of Music, Martinus Nijhoff, The Hague; Schneider, Marius 1969, Geschichte der Mehrstimmigkeit. Historische und phänomenologische Studien, Hans Schneider, Tutzing; Wiora, Walter 1949, Zur Frühgeschichte der Musik in den Alpenländern, Schweizerische Gesellschaft für Volkskunde, Basel; Wiora, Walter 1957, Europäische Volksmusik und abendländische Tonkunst, Hintenthal Verlag, Kassell; Wiora, Walter 1960, Das Musikwerk. Eine Beispielsammlung zur Musikgeschichte Europäischer Volksgesang. Gemeinsame Formen in charakteristischen Abwandlungen, Volk, Köln.

7 The diffusionist theory in anthropology - one denying that in the aggregate people think and behave in similar ways under similar conditions, or that history can ever repeat itself-is contrasted with that of polygenesis, which holds that very similar stories, artefacts and cultural attitudes more generally may originate independently in different parts of the world since man was often confronted by similar needs and challenges. For the purpose of my argument, the two positions are, paradoxically, similar. In fact, both processes require a time scale of considerable magnitude in order to unfold. The diffusionist holds that there is homology between universal distribution of cultural traits and their antiquity, because distribution takes time to occur; the polygeneticist comes to the same conclusion, because for something to be reinvented and then be present in different parts of the world much time is necessary. One is reminded in this connection of Jonathan Swift who, in his Gulliver visiting Laputa, suggested that there is a very small probability, but finite, that one could write a profound book by simply scrambling around the letters of the alphabet, which is a way of saying that, given a sufficient amount of time, all cultures could in the end independently come up with the same inventions.

8 I call them 'sound-complemented' performances because organised sound is necessary in order to achieve the performance goal, but it is not in itself 'the' goal; it will not exist for the sake of having a public listening to it with concentrated attention and appreciating the quality of its design.

9 West, Martin Litchfield [1992] 1994, Ancient Greek Music, Clarendon, Oxford, pp. 23-4. 
A popular form in the Middle Ages was the Planctus, a lament to be sung, either in Latin or in the vernacular. ${ }^{10}$ Students taking a course in medieval music get to know at least the Planctus Karoli written for the death of Charlemagne (814) and, in the thirteenth century the Planctus Mariae (dedicated to the Virgin Mary). ${ }^{11}$ In Italy during the nineteenth century an anonymous estampie, called 'Il Lamento di Tristano', was widely circulated. ${ }^{12}$ There was, of course, the Requiem Mass, the Miserere and, in the Baroque period, the French Tombeau. ${ }^{13}$ In late madrigals and in early operas (by Monteverdi and Cavalli, for instance), a 'lament' was often encountered and it stylistically required a descending ostinato bass figure. ${ }^{14}$ In the oral environment of Western culture an even greater variety of forms and genres exists as well, serving the purpose of expressing grief or, more generally, some sense of loss, like, for instance, in 'weeping wedding' ceremonies. ${ }^{15}$

Yes, grief is universal, but cultures deal with it differently. ${ }^{16}$ Depending on where and when we live, grief is something we may need to express, communicate, share or even 'represent'. Incidentally, one needs to be careful because terms such as 'express' and 'communicate' are not interchangeable. We may express ourselves through organised sound, and yet that form of expression may be meaningless to anyone else. If, on the contrary, it is regarded as meaningful and is understood, the result is both expression and communication. We may actually wish to go even further and not just communicate, but also share with others the experience of loss, and one way to do so is by bringing people into a ritual meant for that purpose. We may even wish to have our grief 'represented', framed, put on stage, so to say, for ourselves and others to see and contemplate. This, also, is one way to let everybody know we are going through a traumatic experience, and should be treated accordingly, because, under emotional strain as we are, we may not behave or react in our usual manner. ${ }^{17}$

10 De Martino, Ernesto [1958] 1975, Morte e pianto rituale nel mondo antico: dal lamento pagano al pianto di Maria, Einaudi, Torino, pp. 195-210.

11 Reese, Gustave 1940, Music in the Middle Ages: With an introduction on the music of ancient times, Norton, New York, p. 198; Hoppin, Richard H. 1978, Medieval Music, Norton, New York, pp. 257-9.

12 Reaney, Gilbert 1960, 'Ars Nova', in Alec Robertson and Denis Stevens (eds), The Pelican History of Music. Volume 1: Ancient forms to polyphony, Penguin Books, Baltimore, pp. 261-322.

13 Vendrix, Philippe 1989, 'Il tombeau in musica nel periodo barocco', Nuova Rivista Musicale Italiana, vol. 23, no. 3, pp. 325-41.

14 Hill, John 2005, Baroque Music. Music in Western Europe, 1580-1750, Norton, New York, p. 197. This 'lamenting bass' (a bass line descending by half steps) was a standardised procedure, presumed by eighteenthcentury composers to 'represent' the Affekt of sadness.

15 Ling, Jan 1997, A History of European Folk Music, University of Rochester Press, Rochester, NY, pp. 50-3, 58-9.

16 De Martino, Morte e pianto rituale nel mondo antico, pp. 111-16.

17 Ibid., pp. 12-24. 


\section{Section IV. Expression versus Representation}

'Representation' over direct 'expression' is often a cultural choice. In fact, in music history courses we explain to our students how, whereas nineteenthcentury composers were expected to 'express' their feelings and pour them into their music, in the Baroque period the Affektenlehre (the 'Doctrine of Affections') required a different, totally 'un-Romantic', attitude. It maintained that by using proper standard procedures (the descending ostinato bass figure mentioned above was one of them), a capable composer could 'represent' emotions so effectively as to produce in the audience a corresponding response (not unlike what happens in film music, where the composer is not supposed to express his own emotions, but, rather, those felt by the portrayed characters, or suggest to the audience how they should feel about the action). Theories of acting developed during the twentieth century were also concerned with the expression versus representation dilemma-both finalised to communication. Constantin Stanislavskij and Lee Strasberg (the founder of the Actors Studio in New York) believed actors should forget who they are and become the character itself; it is easy to sense in this wish to offer the public true emotions some late-Romantic overtones. ${ }^{18}$ Johann Wolfgang Goethe, on the contrary, did not believe theatre (musical theatre included) should even try to give the illusion of reality, because the audience, by attending a performance, automatically accepts the idea of representation. ${ }^{19}$ Berthold Brecht with his 'Dialectic Theatre', where acting is a form of social critique, bypassed with one single stride the whole expression versus representation dilemma; ${ }^{20}$ and the celebrated actor Marcello Mastroianni, in several interviews, simply expressed the idea that actors do not have to feel like the character they are portraying, they just need to put some conviction into their actions. ${ }^{21}$

I find this whole question of 'expression' versus 'representation' intriguing, because ethnographic experience shows that even oral cultures go either one way or the other. In fact, when grief needs not only to be expressed but also to be communicated, socially shared, it is often felt that the effectiveness of communication can be increased through a formalised behaviour that will give grief a somewhat theatrical dimension. In that case people learn to express and channel their sorrow according to patterns that the community understands

\footnotetext{
18 Stanislawskij, Constantin 1981, La construction du personage, Pygmalion, Paris.

19 Goethe, Johann Wolfgang 2005, 'Über Wahrheit und Wahrscheinlichkeit der Kunstwerke. Ein Gespräch', Schriften zur Kunst, Schriften zur Literatur, Maximen und Reflexionen. Volume 12, Edited by Erich Trunz, C. H. Beck, München.

20 Reich-Ranicki, Marcel 1996, Ungeheuer oben. Über Bertold Brecht, Aufbau-Verlag, Berlin.

21 Back in the 1980s I watched Marcello Mastroianni on American television, interviewed by Dick Cavett. On that occasion I heard him say an actor does not need to feel like his character does, only that, if the character has to say 'good morning', the actor should simply be fully aware he is wishing somebody a 'good morning' and do it properly!
} 
and appreciates. Cultures do not just let us cry and despair in any way we might possibly like. They give us constraints, which are part of the socialisation process, which we assimilate as we grow up, and which lead us to react to sorrow in a manner that is culture-specific and not universal. That is why Scandinavians are usually surprised at how grief is expressed in Mediterranean cultures, and vice versa. The perception in Northern Europe is that in the south grief becomes spectacle when mourners not only cry, but may even need to be restrained, lest they pull their hair out or self-inflict bleeding wounds. The perception in the south is, on the contrary, that Scandinavians, who may not even shed a tear during a funeral ceremony, react in such an introverted, 'cold' manner that 'southerners' may even wonder whether they really experience any profound sense of bereavement and loss - which, of course, they do.

\section{Section V. The Professionalisation of Sorrow}

In traditional societies, the formal vehicle for communicating and representing sorrow may have to be so sophisticated that the 'performance' has to be delegated to professionals. They are people, usually women, who obviously do other things as well in life, but develop specialised skills that can be exhibited during mourning ceremonies, and which they will exhibit with adequate compensation. This is nothing to be surprised about. Let us consider how expensive funerals are in urban society and how, although often without music, they serve a similar function.

In the Mediterranean area from antiquity, and certainly in southern Italy, Corsica and Romania until the 1950s, professional wailers were usually hired to perform laments. In Apulia and Calabria they were named rèpute or chiangimorti; in Sardinia attitadoras; in Corsica voceratrici (and there are in Corsica 'categories' of lament: the voceru for those who die a violent death and the lamentu for those who die a natural death). In Romania the lament is called Bocet. A study of the Romanian Bocet by Constantin Brailoiu was one of the elements on which anthropologist Ernesto De Martino developed his epoch-making study of Death and Ritual Wailing in the Ancient World. ${ }^{22}$

Professional wailing in Mediterranean cultures was performed only by women, and by those capable of giving in their performance the appearance of a total, unrestrained, overwhelming emotion, accompanied by streaming tears and sobbing that intermittently cut off the narrative of their wailing: the life, merits and deeds of the deceased. It was such an effective representation of sorrow 
that it could have (and was expected to have) some kind of cathartic, healing effect for the immediate circle of the deceased, and inspire a sense of respectful empathy by the more distant relatives or the village at large.

\section{Section VI. When Ritual Mourning Goes Literate}

Let me now go back to the Western literate tradition, and recall how my first and most vivid memory of a lament relates, in fact, to the written music of Europe. It is a piece my professor of composition gave me once to analyse and admire: Josquin des Prez, 'Déploration sur le trépas de Jean Ockeghem' ('Lament on the passing away of Jean Ockeghem'). ${ }^{23}$ Here Josquin des Prez, arguably the greatest composer of the Renaissance, expresses his sorrow for the passing away of Johannes Ockeghem, who had been his teacher. That piece by Josquin, already famous in his own time, made the sad news public across Europe that the great Ockeghem was dead.

Compositions of this type have a long history, although they are seldom mentioned and remembered. It is one intriguing and puzzling aspect of our Western mentality that so-called masterpieces can only occur within certain genres or through specific instruments or ensembles. A symphony can be a masterpiece (and many of them are considered such), but not a brass-band fanfare or a piece for mandolin. In fact, Beethoven once wrote four mandolin pieces for a friend who played that instrument and none of them has ever been elevated to the pantheon where the great (supposedly) immortal works are collected and venerated. Music in commemoration of, and expressing regret for, the passing away of someone also has little chance of being recognised as a masterpiece unless it is pretentious, monumental and, by losing its original connotation, becomes a concert piece. The Requiem Mass usually qualifies, and many great composers produced one that entered the repertoire (thereby losing its original 'lament' quality): Mozart, Cherubini, Brahms, Berlioz, Verdi, Gounod, Fauré, Lygeti, Penderecki. ${ }^{24}$ Mysteriously, other composers failed: Haydn, Donizetti (he wrote a mass to lament the death of Bellini) and Schumann, amongst several others.

\footnotetext{
23 Reese, Gustave 1954, Music in the Renaissance, Norton, New York, pp. 118, 235, 245.

24 Giuseppe Verdi's requiem composed for Alessandro Manzoni is probably the most famous and most often performed of all. It is also an example of how theatrical a 'lament' can be. In fact, it was described with the following words: 'Verdi's Requiem is a work which defies all the canons of good taste. It is melodramatic, sentimental, sometimes almost cheap; it employs without shame such well-worn means to excitement as the diminished seventh and the chromatic scale. Yet it is one of the greatest works of art and gained the reluctant admiration of a composer with a much different artistic philosophy, Brahms' (Vaughan-Willliams, Ralph 1953, Some Thoughts on Beethoven's Choral Symphony with Writings on Other Musical Subjects, Oxford University Press, Oxford, p. 57).
} 
We do find in the literate tradition compositions that in spirit are more connected to the idea of 'lament' as we find it practised in the oral environment. I am thinking, for instance, of Igor Stravinsky's 'Dirge-Canons and Song: In Memoriam Dylan Thomas' of 1954. If we made the effort of putting together the whole repertoire of pieces composed with a similar intention, an interesting aside to music history would appear - one very rich in curiosities. For instance, just imagine: Viennese composer Anselm Hüttenbrenner (1794-1868), a good friend of Schubert's, was almost a specialist in the genre. He is in fact the author of a musical lament, to be played on the piano, for Beethoven's passing in 1827 (Nachruf an Beethoven in Akkorden) and, one year later, for Schubert (Nachruf an Schubert in Trauertönen).

The reason I find it appropriate to mention in this article much music that does not fall under the purview of ethnomusicology is that if we look at the literate tradition anthropologically, here we recognise once again - just like we do in the oral environment - the need to have sorrow professionally interpreted, expressed and represented so that it may become publicly contemplated and shared. What we find in the literate tradition ultimately is the surface manifestation of needs and practices widespread all along, and much earlier also, in the oral environment.

\section{Section VII. Is It Music or What?}

But, of course, what we find in the literate tradition is...'music'! Funeral laments as we know them in traditional environments, on the contrary, are not necessarily to be categorised as such — not in the Mediterranean area. Here we are talking about forms of behaviour that have their roots in classical antiquity

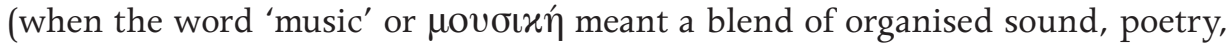
dance, physical exercise and even medical practice - that is, profoundly different from what it means today) and managed to survive in contemporary Christian and Islamic cultures, often frowned upon by religious orthodoxy. Surely the Christian Church tried as much as possible to erase everything reminiscent of pagan practices, such as traditional 'laments' among others.

Indeed, in antiquity the concept of 'music' was so quite unlike the one we have today (that could be a story in itself) that when we say that the ancient Egyptians, Greeks and Romans had 'music' we are simply looking at the past, as if it were an extension of the present. That is a risky thing to do because, as Leslie P. Hartley reminds us at the outset of his celebrated novel The Go-Between: 'The past is a foreign country. They do things differently there. ${ }^{25}$ In antiquity 
our concept of music was unknown, and that is why I feel uncomfortable calling 'music' what, back then, went by other names. For the purpose of scholarly investigations I feel it would be more appropriate to use terms that have no historical or ideological connotations, terms such as 'sound-centred', 'sounddependent', 'sound-enhanced' or 'sound-complemented forms of behaviour'. It is actually worth considering whether it makes any sense at all-in scholarly and scientific discourse - to speak about 'music' in general as well. Here we have a veritable 'word of mass deception', charged with Romantic overtones; indeed, not a scientific term at all, and one that helps us overlook nuances rather than helping us assess subtleties. ${ }^{26}$ We categorise far too many things under this label: a funeral lament, a Bruckner symphony, a medieval organum, a TV jingle. They all are forms of organised sound, although made for essentially different purposes. It is almost as if we spoke of 'metal things', while failing to observe that a knife does not really deserve to be put in the same category as a nail or a screwdriver. It is almost as if we put into the same category such different things as the Princes Highway in Australia, the Magnificent Mile in Chicago, the floor of my Lugano apartment and the surface of the desk I am using right now, only because - if one really wanted to - one could dance on such surfaces, and then created the category of 'danceables'. It would make no sense at all.

Be that as it may, Judaism, Christianity and Islam have expressed mixed feelings towards organised sound all along because of its physical, sensual and bodyactivating power, especially when referred to as 'music'. All three have elaborated an entire philosophy of what music is appropriate to have, and when. ${ }^{27}$ So, just as Koranic cantillation is not classified as 'music' in Muslim cultures (it would be disrespectful to sing the Word of God) and, by the same token, lament practices across traditional Mediterranean cultures are not classified as 'music' either, it would be inappropriate to sing a 'song' in the presence of the dead. In other words, a lament is a 'lament' and nothing else. In many cultures funeral laments may be seen as falling into the category of excited speech, emotional speech, solemn speech, call, address, invocation, weeping, and so on. Rather than putting too many things into the same basket, and calling them 'music', as we so often do, it would be worth considering retaining the terminology actually applied by the people who do those things - unless we wish to apply a term that can be applied cross-culturally. Perhaps we should speak of 'sound-dependent' activities, because in most traditional cultures a lament, although not considered 'music', is simply not conceivable without its reliance on organised sound.

In the literate tradition, on the contrary, it is quite appropriate to call expressions and representations of grief and bereavement 'music'. It is the literate tradition

\footnotetext{
26 Sorce Keller, 'Was ist Musik?'.

27 During Lent, for example, many Catholics refrain from forms of sonic behaviour that may be construed as 'music'.
} 
that in recent times (historically speaking) has developed a concept of 'music' and 'art' that is quintessentially noble, and a religion of sorts. Art and music in the cultivated tradition are supposed to elicit not just pleasure and emotional response but veneration. In fact, in a concert setting, when confronted with the absolute Musik, with a musical work regarded as 'immortal', we are expected, if not actually to genuflect, at least to sit motionless and keep silent. ${ }^{28}$ When organised sound comes to be conceived in such unusual terms - as an anthropological singularity limited to the West and cultures that have come under its influence - it surely can be seen as the appropriate means to express and represent grief and sorrow. At that point one could almost maintain that without 'music' no such expression and representation are complete.

\section{Section VIII. Conclusions (Sort of...)}

By way of conclusion, in order to end on a lighter tone, I would like to remind my readers that laments also exist that are not entirely serious: they range from the grotesque to the tongue-in-cheek. They make up a mixed genre. The 'Ballad of Mack the Knife' in Kurt Weill's The Threepenny Opera is one such case. It belongs to the German genre called Moritat. A Moritat (from Latin mori meaning 'deadly' and tat meaning 'deed') is a kind of murder ballad performed by strolling minstrels. In The Threepenny Opera, the Moritat singer with his street organ introduces and closes the drama with the tale of the deadly Mack the Knife, the character based on the dashing highwayman Macheath in John Gay's The Beggar's Opera.

There is Gluck's famous aria 'J'ai perdu mon Eurydice, rien n'égale mon maleur' ('I have lost my Eurydice, nothing equals my grief'), whose music, according to Eduard Hanslick, equally well fits words expressing the contrary sentiment: 'J'ai trouvé mon euridyce, rien n'égale mon bonheur' ('I have found my Eurydice, nothing equals my joy'), in which case we would have a lament about 'presence', rather than about absence and loss. ${ }^{29}$ Another lament about a condition of presence would be the old song in which Louis Armstrong used to sing 'What Did I Do, to Be so Black and Blue'.

Another intriguing case exists in a 1938 set of recordings, made for the Library of Congress by Alan Lomax with Jelly Roll Morton, the legendary pianist-

\footnotetext{
28 The irony of the absolute Musik - of music that wants to be appreciated as 'music' and nothing else - is that the concept was formulated by Richard Wagner, precisely to suggest that such a thing could not possibly exist; and then it became the flag of formalist aesthetics formulated by Wagner's enemy, Viennese critic Eduard Hanslick, who actually believed that the absolute Musik is the only music worthy of this name! Hanslick, Eduard [1854] 1957, The Beautiful in Music, Translated by Gustav Cohen, Bobbs-Merrill, Indianapolis; Pleasants, Henry (ed.) 1988, Hanslick's Music Criticisms, Dover, New York.

29 Hanslick, The Beautiful in Music.
} 
composer from the bygone days of New Orleans jazz. In 'Funeral Marches', softly strumming the keys, Jelly Roll Morton conjured up a New Orleans funeral, from the wailing dirge to the graveyard, to the raucous march back to the wake, with all its sorrow and jubilation - in his words, 'the end of a perfect death'. ${ }^{30}$

The last case I would like to mention is actually not about death at all, although it is about loss, the loss of something very precious indeed: the ability to see. Saverio Mercadante (1795-1870), in his time arguably the most famous opera composer in Europe, became completely blind in 1862. That same year he managed to dictate to his pupils a full-scale orchestral piece, with the apparent autobiographical title of Il lamento del bardo (The Bard's Lament). Contrary to what one might imagine, it is an entertaining, witty piece, in which Mercadante, far from feeling sorry for himself, actually communicates a sense of comic irony. The blind musician is one of literature's oldest themes; it dates back at least as far as the Middle Kingdom of ancient Egypt. And then there are of course Homer and the Irish bard O'Carolan, with many others in between and afterwards. Mercadante, in a way, makes us understand how he felt: that by becoming blind, he was now in very good company. This is as good a case as any to remind us all of the therapeutic value of expressing, communicating, representing and sharing grief and sorrow.

\section{Bibliography}

Caraveli-Chavez, Anna 1980, 'Bridge between worlds: the Greek women's lament as communicative event', Journal of American Folklore, vol. 368, no. 93, pp. $129-57$.

Clericetti, Giuseppe 2004, 'Musica e Morte in ambito profano: Déploration, Lamento, Tombeau', Altri Sguardi, vol. 3, pp. 86-90.

Dahlhaus, Carl 1978, Die Idee der absoluten Music, Bärenreiter, Kassel.

Danckert, Werner [1939] 1970, Das europäische Volkslied, Bouvier u. Verlag, Bonn.

Danforth, Loring M. 1982, The Death Rituals of Rural Greece, Princeton University Press, Princeton, NJ.

De Martino, Ernesto 1955, 'Considerazioni storiche sul lamento funebre lucano', Nuovi Argomenti, vol. 12, pp. 1-33.

30 Morton, Jelly Roll 2005, The Complete Library of Congress Recordings, Library of Congress, Washington, DC. 
Harrison, Simon 1982, Laments for Foiled Marriages; Love Songs from a Sepik Village, Institute of Papua and New Guinea Studies, Boroko.

Macchiarella, Ignazio 1991, 'La combinazione di stereotipi armonico-melodici in un repertorio di tradizione orale: I lamenti di Mussomeli', in M. Baroni e and R. Dal monte (eds), L'analisi musicale, Unicopli, Milano, pp. 144-50.

Parkes, Colin Murray, Laungani, Pittu and Young, Bill 1997, Death and Bereavement Across Cultures, Routledge, London.

Reinhard, Kurt 1984, 'Gestalten südtürkischer Totenklagen', in C. Ahrens, R. M. Brandl and F. Hoerburger (Hrsg.), 'Weine meine Laute...'-Gedankschrift Kurt Reinhard, Laaber Verlag, Laaber, 15-36.

Rosand, Ellen 1979, 'The descending tetrachord: an emblem of lament', $M Q$, vol. 65 , no. 3, pp. 346-59.

Rouget, Gilbert 1980, La musique et la transe. Esquisse d'une théorie générale des relations de la musique et de la possession, Gallimard, Paris.

Tolbert, Elisabeth Dawn 1988, The musical means of sorrow: the Karelian lament tradition, University of California, Los Angeles (PhD Dissertation reviewed in The World of Music, vol. 2[1991], pp. 109-11).

Zimmermann, Otto 1899, Die Totenklage in den altfranzösischen Chansons de Geste, E. Ebering, Berlin. 